Historia: Jurnal Program Studi Pendidikan Sejarah

Vol. 2 No. 2 (2017):33-40

P-ISSN 2301-8305

E- ISSN 2599-0063

\title{
PERISTIWA G-30-S/PKI DI BALIK PENETAPAN HARI KESAKTIAN PANCASILA TAHUN 1965
}

\section{G-30-S/PKI EVENT BEHIND THE ESTABBLISHMENT OF THE 1965 PANCASILA MAGIC DAY}

\author{
Fitri Yanti \\ (Prodi Pendidikan Sejarah,FKIP, Universitas Riau Kepulauan) \\ Fit.ugm@gmail.com
}

\begin{abstract}
Abstrak
Penelitian bertujuan untuk mengetahui latar belakang Persitiwa G-30-S/PKI di Balik Penetapan Hari Kesaktian Pancasila Tahun 1965. Penelitian ini dilakukan dengan menggunakan metode analisis kualitatif dengan mengunakan pendekatan histories (sejarah), sebab untuk mengungkapkan kejadian masa lampau haruslah menggunakan metode yang tepat. Dalam penelitian ini penulis menggunakan teknik pengumpulan data diantaranya sebagai berikut: Teknik studi kepustakan, teknik dekumentasi, dan teknik studi komperatif. Hasil penelitian ini akan menjelaskan latar belakang Peristiwa G-30-S/PKI yang terjadi di Balik Penetapan Hari Kesaktian Pancasila pada Tahun 1965 tersebut yang bersangkutan dengan pemberontakan dan pengkhianatan PKI "Gerakan 30 September"nya merupakan ujian yang berat bagi ketangguhan dan keampuhan Pancasila. Pemberontakan itu, yang jelas bermaksud merebut pimpinan negara dan mengkomuniskan Indonesia, di awali dengan penculikan, penganiayan diluar prikemanusian dan pembunuhan terhadap tujuh Pahlawan Revolusi pada dini hari 1 Oktober 1965. Kemudian 1 Oktober diperingati sebagai hari Kesaktian Pancasila oleh bangsa Indonesia.
\end{abstract}

\section{Kata kunci: $P K I$}

\begin{abstract}
Research aim to to know background of Persitiwa Returned by Stipulating Of Day Miracle of Five Principles Year 1965. This research is done/conducted by using method analyse qualitative with mengunakan approach of histories ( history), cause to lay open old world occurence shall use correct method. In this research of writer use data collecting technique among others as follows: Study technique of kepustakan, technique of dekumentasi, and study technique of komperatif. Result of this research will explain Event background is that happened Returned by Stipulating Of Day Miracle of Five Principles in the year 1965 the which dealt only with rebellion and betrayal of PKI "Its Movement 30 represent heavy test to delaying and keampuhan of Five Principles. That Rebellion, clear mean to grab state head and communize Indonesia, in fist with abduction, penganiayan outside murder and prikemanusian to seven Warrior Revolutionize at early morning 1 October 1965. Later;Then 1 commemorative October as day Miracle of Five Principles by Indonesian nation.
\end{abstract}

Keywords: $P K I$

\section{PENDAHULUAN}

Setiap bangsa di dunia memiliki peristiwa/sejarah masing-masing terhadap kelangsungan hidup dari bangsa dan negaranya, untuk mengetahui suatu peristiwa atau 
Historia: Jurnal Program Studi Pendidikan Sejarah

Vol. 2 No. 2 (2017):33-40

P-ISSN 2301-8305

E- ISSN 2599-0063

kejadian dari suatu bangsa kita perlu untuk mengetahuinya dari sejarah. Sejarah itu sendiri ialah salah satu bidang ilmu yang meneliti dan menyelidiki secara sistematis keseluruhan pengembangan masyarakat serta kemanusian di masa lampau, beserta segala kejadiankejadian dengan maksud untuk kemudian menilai secara kritis seluruh penelitian dan penyelidikan tersebut, untuk akhirnya dijadikan pembedaharaan pedoman bagi penilaian dan penentuan keadaan sekarang serta arah program masa depan (Depdikbud, 1985:4)

Pentingnya peranan sejarah bagi pengetahuan seseorang menuntut setiap pribadi mau tak mau harus mempelajari peristiwa-peristiwa masa lampau khususnya peristiwa yang terjadi pada bangsa Indonesia. Mempelajari sejarah berarti memberikan harapan kepada setiap individu dapat memahami suatu perkembangan dan pola pemikiran sehingga dari sejarah yang dipelajari itu akan tumbuh ilmu pengetahuan dan pelajaran hidup yang dapat diambil didalamnya. Setelah itu, hal yang baik di kembangkan dalam kehidupan pada bidang sosial, politik, kebudayaan, dan sebagainya.

Sejarah telah membuktikan, betapa ampuh dan mendarah dagingnya Pancasila sebagai keperibadian bangsa Indonesia dan dasar Negara Republik Indonesia dalam menghadapi semua tantangan atau rintangan dari pihak aliran-aliran yang anti Pancasila. Sejak berdirinya Negara yang di Proklamasikan 17 Agustus 1945 yang berdasarkan Pancasila telah berulang kali terjadi tragedi nasional yang sebab-musababnya terletak pada kelengahan dan kurang kewaspadaan dari pemimpin rakyat pada umumnya. Hal tersebut dapat kita lihat dan kita buktikan dengan terjadinya pemberotakan diantaranya PRRI/Permesta, DI/TII dan lain-lainnya yang syukur Alhamdulillah berkat lindungan Tuhan Yang Maha Esa seluruhnya dapat digagalkan.

Yang merupakan ujian terberat bagi keampuhan dan kesaktian Pancasila adalah pemberontakan yang dilakukan oleh G-30-S/PKI dimana seluruh kekuatan dan kemampuan dari pengkhianatan G-30-S/PKI digunakan dalam segala bentuk dan cara untuk melakukan gerakan dan tipu daya yang jahat yang hampir-hampir dapat mengelabui rakyat untuk membelokkan jalanya keluar dari dasar Pancasila.

Tetapi berkat rahmat Tuhan Yang Maha Esa maka timbullah secara serentak pada 1 Oktober 1965 manifestasi daripada seluruh kekuatan dan kesaktian Pancasila dari rakyat Indonesia yang benar-benar yakin akan kebenaran Pancasila sebagai satu kekuatan ampuh 
Historia: Jurnal Program Studi Pendidikan Sejarah

Vol. 2 No. 2 (2017):33-40

P-ISSN 2301-8305

E- ISSN 2599-0063

yang bertindak secara tegas dan tepat untuk meluruskan jalannya perjuangan kepada relnya Pancasila.

\section{Mengapa Pancasila Sakti?}

Dalam lembaran sejarah perjuangan bangsa Indoensia terbukti bahwa Pancasila telah berkali-kali mengalami percobaan untuk dirongrong dan diselewengkan oleh berbagai golongan yang anti terhadap prinsip-prinsip falsafah Pancasila. Akan tetapi berkat pertolongan Tuhan Yang Maha Esa, maka setiap kali pula Pancasila dapat bertahan dan menunjukan keampuhannya. Berkat Pancasila yang dengan ridha Tuhan Yang Maha Pemurah dan Mahabijaksana, maka bangsa Indonesia berhasil menumpas setiap bentuk pemberontakan dan penyelewengan yang bertujuan untuk menghancurkan Pancasila dari bangsa Indonesia.

Pancasila yang telah kita akui sebagai Dasar Negara Republik Indonesia itu pada hakekatnya merupakan suatu jalan pikiran dan dasar falsafah hidup bangsa Indonesia. Dasar falsafah tersebut tidak dapat dipisahkan dari sejarah pertumbuhan bangsa Indonesia sejak dahulu kala. Nilai-nilai yang tercakup dalam pancasila telah merupakan kepribadian bangsa Indonesia sejak dahulu dan terus berkembang sesuai dengan perkembangan dan pertumbuhan bangsa Indonesia. Namun nilai-nilai tersebut tetap akan meninggalkan hakekat inti kemurniannya, yaitu manusia dan bangsa Indonesia yang dikodratkan lahir dan hidup di bumi serta alam Indonesia. Nilai-nilai tersebut telah merupakan suatu dasar dan perkembangan hidup yang mengendalikan bangsa Indonesia di tengah-tengah kehidupan bangsa-bangsa di dunia ini.

Sebagai falsafah hidup, Pancasila mengandung dasar-dasar daripada suatu pandangan hidup manusia yang ber-Tuhan. Setiap manusia mempunyai kepercayaan kepada Al-Khalik, Tuhan yang jika semua kita percaya dan takut kepada kekuasaan Tuhan, pasti hal ini akan mempengaruhi secara berfikir kita semua, cara kita diantara sesama manusia dibawah satu naungan dan kekuasaan Tuhan Seru Sekalian Alam.

\section{Kerangka Teoritis}

Dengan diabdikan peristiwa pengorbanan para Pahlawan Revolusi dalam mengahadapi teror G-30-S/PKI, berupa Peringatan Hari Kesaktian Pancasila dan pembangunan monumen Pancasila Sakti kepada bangsa Indonesia khususnya dan dunia 
Historia: Jurnal Program Studi Pendidikan Sejarah

Vol. 2 No. 2 (2017):33-40

P-ISSN 2301-8305

E- ISSN 2599-0063

internasional pada umunya. Akan dapat ditunjukan betapa perjuangan rakyat Indonesia dalam menegakkan dan mempertahankan kemerdekaan bangsa dan negaranya. Dunia internasional akan dapat menilai sampai berapa jauh kerelaan untuk berkorban dan pengorbanan bangsa Indonesia dalam perjuangan untuk membela, mempertahankan dan untuk mencapai cita-cita Proklamasi Kemerdekaan 17 Agustus 1945. Sekaligus akan dapat dimengerti dan dibuktikan mengapa bangsa Indonesia menolak dan menentang ajaran komunis yang menjadi ideologi PKI. Azas-azas Pancasila telah membuktikan kepada dunia internasional bahwa bangsa Indonesia adalah bangsa yang berjuang untuk perdamaian dunia yang abadi di dalam kehidupan antara bangsa atas dasar saling hormat-menghormati.

Bangsa Indonesia yang memiliki pola hidup sebagai suatu bangsa merdeka yang didasarkan atas falsafah Pancasila, mengakui dan menghormati setiap bangsa dengan serta falsafah hidupnya masing-masing, selama tidak merusak, melawan atau memusuhi bangsa dan Negara Republik Indonesia serta ideologi Pancasila. Bangsa Indonesia akan menentang dan menghancurkan segala bentuk usaha yang memusuhi, mencemarkan apalagi yang merusak dan menghancurkan Pancasila, dengan maksud untuk menukar falsafah Pancasila dengan ideologi komunisme, maka seluruh kekuatan PKI ditumpas habis dan dinyatakan sebagai partai terlarang, serta dilarang pula ajaran komunis berkembang diseluruh wilayah Negara Republik Indonesia.

\section{METODOLOGI}

Jenis penelitian ini kualitatif dengan metode historis. Metode historis terdiri dari Heuristik, kritik sumber, interpretasi, dan historiografi. Teknik pengumpulan data dalam penelitian ini yaitu dilakukan dengan cara studi kepustakaan dan melakukan kritik baik intern seperti isi sumber, bahasa yang dipergunakan, situasi penulisan, gaya dan ide maupun ekstern seperti bentuk sumber, tanggal, waktu dan pengarangnya. Teknik analisa data yang dipakai untuk penulisan ini adalah metode historis. Tempat penelitian dilakukan di perpustakaan dan tempat-tempat yang mendukung hingga penelitian ini bisa terselesaikan.

\section{PEMBAHASAN}

\section{Situasi Yang Mendukung}


Historia: Jurnal Program Studi Pendidikan Sejarah

Vol. 2 No. 2 (2017):33-40

P-ISSN 2301-8305

E- ISSN 2599-0063

Partai Komunis mau tunduk kepada ketentuan pemerintah, menerima ideologi nasional hanya sebagai alat agar mereka diberi hak hidup. Akan tetapi begitu kekuatan dan pengaruhnya sudah besar, "kesetian dan kepatuhan" segera ditinggalkan. Kenyataan itu dapat dilihat pada tahun 1965. Pada saat pengaruh PKI sudah mendominasi percaturan politik nasional, pernyataan tunduk pada "Pancasila hanya sebagai alat pemersatu dan kalau sudah bersatu Pancasila tidak diperlukan lagi”.

\section{Dominasi PKI di bidang Politik}

Sejak awal kebangkitan PKI pada tahun 1950, mereka merubah pola politik dari ekstrim kepada politik kerjasama. PKI merasakan banyak pihak yang terus merasa curiga terhadap PKI. Karena itu PKI membina kerjasama dengan salah satu partai besar yang tidak memusuhinya yaitu kelompok Nasionalis (PNI). PKI menyadari kerjasama ini menguntungkan PNI, tetapi bagi PKI yang terpenting bahwa kebijaksanaan pemerintah tidak merugikan perjuangan PKI.

\section{Kebijakan Politik Dalam Negeri Menguntungkan PKI}

Dukungan PKI tanpa reserve terhadap kebijakan Presiden Soekarno, dibalas oleh Presiden Soekarno dengan memberikan konsesi-konsesi politik kepada PKI yang dianggapnya sebagai partai yang revolusioner. Kepercayaan yang diberikan ini oleh PKI dimanfaatkan utuk memasukan Program PKI sebagai Program Nasional. Program Manipol tidak lain program MIRI PKI seperti yang diakui sendiri oleh Sjam Kamarurzaman, yang menyatakan melaksanakan Manipol dengan baik berarti melaksanakan program PKI dengan baik pula. Demikian pula halnya dengan program Nasakom, merupakan pemenuhan tuntutan PKI untuk duduk dalam pemerintahan dari Pusat sampai ke daerahdaerah yang tadinya pengaruh PKI masih lemah, mendapat kesempatan berkembang, karena mereka pun harus terwakili di lembaga pemerintahan maupun DPRD. Di sini terlihat bahwa kebijaksanaan pimpinan nasional turut menyuburkan perkembangan PKI.

\section{Kebijakan Politik Luar Negeri}

Politik penjajahan negara Barat (kapitalisme) terhadap negara Asia dan Afrika serta Amerika Latin menimbulkan pergolakan di negara-negara tersebut. Gelora semangat anti 
Historia: Jurnal Program Studi Pendidikan Sejarah

Vol. 2 No. 2 (2017):33-40

P-ISSN 2301-8305

E- ISSN 2599-0063

penjajahan (nekolim) itu dimanfaatkan oleh negara-negara Komunis, yang bertindak selaku pahlawan pembebasan nasional untuk menanamkan pengaruhnya. Keadaan ini dimanfaatkan oleh PKI dengan mempengaruhi Presiden Soekarno, untuk menentang pembentukan Federasi Malaysia yang upaya Nekolim untuk mengepung Indonesia.

Perjuangan membebaskan Irian Barat dilakukan dengan mengerahkan segenap kemampuan bangsa Indonesia tidak terkecuali di bidang ekonomi. Rencana pembangunan ekonomi yang digariskan Presiden Soekarno tidak berjalan, karena titik berat perjuangan terfokus pada bidang politik mercu suar. Keadaan ekonomi yang suram ini dibebani lagi oleh perjuangan baru yaitu mengganyang Malaysia. PKI memang sengaja menciptakan situasi yang demikian untuk menghilangkan kepercayaan rakyat kepada pemerintah. Dengan liciknya PKI menyebut kebobrokan ekonomi karena pemerintah belum melaksankan kabinet berdasarkan Nasakom. Karena itu PKI bersama ormas-ormasnya menuntut pembentukan Kabinet Nasakom sekarang juga. PKI itu sama sekali di luar sasaran, padahal mereka sengaja berbuat supaya keadaan ekonomi collapse, sebagai prasyarat merebut kekuasaan negara.

\section{Tersedianya Tenaga Terlatih (Sukwan) Yang Besar}

Perjuangan Pembebasan Irian Barat (Trikora) dan konfrontasi dengan Masaysia (Dwikora) telah dimanfaatkan oleh PKI untuk melatih sukarelawan-sukarelawan di berbagai pelosok. Tidak hanya sampai di situ, PKI menuntut pada pemerintah untuk mempersejatai mereka. Pada saat hangat-hangatnya perjuangan Dwikora awal 1965, PKI bersama semuanya ormasnya dengan gencar menuntut mempersenjatai kaum buruh dan tani mengahdapi serangan imperialis.

\section{Penguasaan Media Massa Oleh PKI}

PKI menyadari besarnya peran media massa. Sebab itu menjadi salah satu program PKI untuk menguasai media massa dan menghancurkan media massa kekuatan politik lain yang menentangnya. Sampai awal tahun 1965, PKI berhasil menguasai media massa. Semua surat kabar dan majalah yang tidak selaras dengan garis politik PKI dicabut Surat Ijin Terbitnya. Surat kabar atau majalah tersebut dituduh sebagai antek BPS.

\section{KESIMPULAN}


Historia: Jurnal Program Studi Pendidikan Sejarah

Vol. 2 No. 2 (2017):33-40

P-ISSN 2301-8305

E- ISSN 2599-0063

Terdapat dua peristiwa yang terjadi yaitu PKI Melancarkan KUP Pengkhianatan dan Pemberontakan serta peristiwa-Peristiwa penculikan dan Pembunuhan pejabat TNI-AD. Peristiwa pemberontakan terjadi di Jakarta pada tengah malam menjelang 1 oktober 1965 sedangkan peristiwa penculikan dikelompokan menjadi Penculikan Menko Hankam/Kasab Jenderal TNI A.H. Nasution, Penculikan Menteri/Panglima Angkatan Darat Letjen TNI A. Yani, Penculik Deputy II Men/Pangad Mayjen TNI Suprapto, Penculikan Asisten I Men/Pangda Mayjen TNI S. Parman Mayjen S, Penculikan Deputy III Men/Panglima Angkatan Darat Mayjen TNI Haryono MT, Penculikan Terhadap Oditur Jenderal Militer/Inspektur Kehakiman AD Brigjen TNI Sutojo, dan Panculikan Asisten IV Men/Pangad Brigjen TNI D.I. Pandjaitan.

\section{REFERENSI}

Arikonto, Suharsini. (2003). Manajemen Penelitian, Rineka Cipat, Jakarta.

Azharny. (2010). Almanak Sejarah Indonesia “ Peristiwa \& Tokoh”, PT. Instisari Mediatama, Jakarta.

Basri. (2006). Metodologi Penelitian Sejarah, Restu Agung, Jakarta.

Buku Panduan Penulisan Karya Ilmiah, UNRIKA, Batam.

Fic, Victo. (2007). Kudeta 1 Oktober 1965, (Sebuah Studi Tentang Konspirasi) Yayasan Obor Indonesia, Jakarta.

Gimin, dkk. (2004). Pedoman Penulisan Karya Ilmiah Mahasiswa Jurusan PIPS FKIP UNRI, Pekanbaru.

Gottschalk, Louis. (2008). Menegrti Sejarah, Terjermahan Nugroho Notosusanto, Unversitas Indonesia Press, Jakarta.

Hendro, Subroto. (2008). Dewan Revolusi PKI (Menguak Kegagalannya Komuniskan Indonesia), Pustaka Sinar Harapan, Jakarta.

Komunisme di Indonesia, Pusjarah TNI Berkerjasama dengan Yayasan Kajian Citra Bangsa ( YKCB), Jakarta 2009.

Lufti, Muctar. (1984). Karateristik Penelitian, UNRI Press, Pekanbaru.

Manafe. (2007). TEPERPU Mengungkap (Penghianatan PKI Pada Tahun 1965 dan Proses Hukum Bagi Pelakunya, PT. Pustaka Sinar Harapan, Jakarta.

M. C. Ricklefs. (2007). Sejarah Indonesia Modern, Gadjah Mada University Press, Yogyakarta. 
Historia: Jurnal Program Studi Pendidikan Sejarah

Vol. 2 No. 2 (2017):33-40

P-ISSN 2301-8305

E- ISSN 2599-0063

Nugroho Notosusanto. (1985). Tercapainya Konsensus Nasional 1966-1969, PN Balai Pustaka, Jakarta.

Pamudi, A. (2006). SUPERSEMAR Palsu (Kesaksian Tiga Jenderal), PT. Agromedia Pustaka, Tangerang.

Poerwadarminta, W. J. S. (1999). Kamus Umum Bahasa Indonesia, Balai Pustaka, Jakarta.

Soegeng, A.Y. (1994). Metode Penelitian, Ghalia Indonesia, Jakarta.

Sudharmono. (1977). 30 Tahun Indonesia Merdeka 1965-1973, Hak Cipta Sekretariat Negara RI, PT. Citra Lamtoro Bung Persada, Jakarta.

Sulastomo. (2000). Hari-Hari Yang Panjang 1963-1966, Buku Kompas, Jakarta.

Sumarkidyo. (2000). Mendung di Atas Istana Merdeka, Pustaka Sinar Harapan, Jakarta.

Suryabrata, Sumadi. (1982). Metode Penelitian, CV. Rajawali, Bandung.

Thamrin Irsyad, (2009). Mereka Menodong Bung Karno (Kesaksian Seorang Pengawal Presiden), Galangpress, Yogyakarta.

Widya, I Gde. (1988). Pengantar Penulisan Karya Ilmiah dan Skripsi, CV. Rajawali, Jakarata.

Windy. (2007). 100 Tokoh Yang Mengubah Indonesia, Narasi, Yogyakarta. 